\title{
"Emerging" through Foreign Investment: Investment Development Path Estimation of "MINT" Economies
}

\author{
Emine Beyza Satoglu
}

Management and Global Business Department, Rutgers Business School, Rutgers University, USA

Copyright $\subseteq 2017$ by authors, all rights reserved. Authors agree that this article remains permanently open access under the terms of the Creative Commons Attribution License 4.0 International License

\begin{abstract}
This article aims to analyze the relationship between the foreign investment, both inward and outward, and the development levels of the emerging market economies: Mexico, Indonesia, Nigeria and Turkey (MINT). Dunning's IDP (Investment Development Path) theory has been used as the basis for empirical analysis covering the recent globalization era: 1990-2013. The fixed effects longitudinal data analysis for the four countries demonstrated that MINT economies are at the $2^{\text {nd }}$ stage of IDP. At the same time, increasing level of inward FDI flows into these countries prove the potential of these economies to be represented as "second generation of fast growing developing countries" after the BRICS. Thus, this study aims to improve our understanding on the emerging economies by focusing on a new group (MINT) and it demonstrates the interaction of inward/outward FDI and the GDP growth in that group of countries.
\end{abstract}

Keywords Investment Development Path, Outward/Inward Foreign Direct Investment, Emerging Economies, MINT

\section{Introduction}

The transformations after the Second World War toward liberalization, deregulation and market system gave rise to the internationalization of the firms, but nothing could be more significant for the globalization of markets than the advances in communication, transportation and technologies boosted in the last two decades. In recent globalization era, the number of the countries and regions benefiting from the advantages of internationalization has expanded sharply. As a result, the level of the Foreign Direct Investment has reached very high levels in all around the world both in developed and developing countries. According to UNCTAD reports [1], global FDI flows have risen to $\$ 1.76$ trillion in 2015. Similarly, the share of FDI flows into developing countries has reached $45 \%$ of global inflows that emphasizes the striking importance of the emerging economies for hosting FDI in recent world. On the other hand FDI outflows from developing countries, which has also reached a record level in 2014, is continued to expand in 2015. In 2015, 28\% of global FDI outflows have been invested by the developing countries, while it was only $12 \%$ at the beginning of the 2000s. [1]

Under the lights of the trends in foreign investment levels, exploring the rise of the share of the developing countries within the total FDI flows has become a new research interest, particularly in the IB field. However, to date, research on the developing countries has still been scarce. The studies that have already been carried out are often of limited to BRICS (Brazil, Russia, India, China, and South Africa) countries or focus on limited time horizon. Similarly, while several studies analyzes the motivations of FDI inflows to developing countries, the key role of both outward and inward investment for the development of the late-industrializer "emerging" economies has not yet well understood. In this regard, the main purpose of this study is to expand our understanding on the emerging economies' development story through an extended time span that would enable us to explore the patterns of development in an interdependent world during the entire years after the globalization of markets in the 1990s. In addition, in this study an unvisited country group that will possibly be accepted as 'the second generation giants of emerging economies' is examined in order to discuss homogeneity or heterogeneity across emerging economies.

\subsection{MINT Economies}

In the history of international business, four waves of MNEs are identified. [2] The first generation of the Multinational Enterprises is the pre-WWI European colonial period that several European multinationals appeared on the global stage. After the WWII, American multinationals dominated the global business networks with a share of 55\% of the world FDI stock. The late 1980s and 1990s Japanese firms expanded in Asia, Europe and the United States. 
Finally the last wave of the multinational expansion is described as the rising of the 'rest of the world' or 'the rising of the share of the emerging markets in FDI stock and in annual flows. Thus, since 1980s, there are more studies committed to analyze the rise of the emerging market economies and their MNEs. These studies distinguish the peculiarities of the emerging markets and compare them to the advanced countries. But, very few studies addressed the heterogeneity across emerging markets, their differences in development levels and related possible differences in FDI behaviors either at the country or firm level. However, the emerging markets are not constituted by a homogeneous group of countries, neither in terms of size and factor endowments, nor of the macro-economic stabilization process, nor of the extent to which they have enacted systemic reforms and, therefore, of their attractiveness to FDI.

Taking the lack of information on the emerging countries into account, one of the main contributions of this analysis is distinguishing the latecomer emerging economies from the first generation fast growing developing countries. Developing countries might follow a different investment-development path than the advanced economies, but also the previously analyzed fast growing emerging economies might differ from the second generation of the emerging economies in their foreign investment patterns. This argument stems from the assumptions that the challenges faced by the latecomers in the international business environment would be much intense to overcome. In order to test this hypothesis, an empirical analysis of a new group of developing countries for their international investment and development relationship is necessary. The estimation results would also help to understand the inward and outward investment positions of these countries. Hence, this paper focuses on how the FDI-development interaction of the developing countries differs from one another. The research question is important because the recent studies focusing on the developing countries, mostly analyzed the features of the BRICS economies and the cross-border operations of their multinationals, but BRICS may or may not be a good reference of the other developing countries due to their peculiar characteristics such as their size, their demographic potential, their national resources and so on.

For the purpose of expanding emerging market studies beyond the BRICS, in this study MINT economies (Mexico, Indonesia, Nigeria, and Turkey) have been analyzed. The Goldman Sachs' Jim O'Neill, the owner of the BRIC acronym, also proposed the acronym MINT in 2013 as 'potential investment destinations' and as 'the second generation of the fast growing developing countries'. [3] Since then, MINT economies recently popularized as a new group for the classification of the emerging market economies. However, yet, there is no academic study to understand MINT's potential for development in association with their inward and outward FDI levels. Thus, the main contribution of this study is its focus on the 'rest of the world' within the emerging markets with references to their investment intensity. In the study, MINT countries have been analyzed using the Dunning's Investment Development Path (IDP) Theory and empirical estimations obtained for the countries in analysis.

MINT economies have some common features that make the grouping relevant. Although their population numbers are modest compared to the BRICS, MINT countries also have growing populations with large amount of young workers. The population of these countries ranges from some 80 million (Turkey) to 240 million (Indonesia). While in developed countries and in China, aging of population and shrinking in size of young labor become a problem, MINT will continue to grow fast with its young population. This characteristic makes MINT countries attractive in terms of foreign investment. Geographically, each of the MINT countries has location advantages placing nearby large-markets. Mexico shares a border with US and has NAFTA agreement with US and Canada, attracting those countries for inward FDI. Turkey borders with Russia and is on the edge of the EU sharing a customs union with EU. Indonesia is close to China and Nigeria is geographically gaining significant advantage as Africa becomes the new destination for the cost-seeking FDI in recent years. Turkey and Mexico, which have reached $\$ 10000$ GNI per capita -Atlas Method- in 2015, have growing middle class and markets. [4] Indonesia and Nigeria, despite the rapid increase in their per capita GNI level towards $\$ 3500$ level, are still lacking behind the upper middle income group. However, due to its high population Indonesia with Turkey and Mexico is member of the G20 largest economies in size. Nigeria even remaining out of the G20 countries, as 23rd largest economy of the world and growing around $6 \%$ in average in the last five years follows the group members as a growing economy. [4]

Five sections compose the paper; the second part clarifies the theoretical model of IDP and summarizes empirical literature of the theory; in the third part the data and the model selection process are explained. Section four evaluates empirical results and makes inference with the results. And, finally in the conclusion section final remarks has been made and the limitations of the study are addressed.

\section{Theory of Investment Development Path and the Empirical Literature}

Growth economists and the experts of international economy have long studied the relationship between economic development and the international investment. In international business theory, Vernon's Product Life Cycle theory (PCM) focused on the relationship between Outward FDI and exports by relating the nature of the product and the development status of the country. [5] Vernon identified three stages for product development: new product, maturing product and standardized product. These stages of the 
products are associated with the country level development; respectively to the most developed countries, developed countries and developing countries.

Relying on the basis of the PCM, Hirsch in 1976 in his International Trade and Development Theory focused on the firm specific dimension of international production for revenue producing. [6] He confined the importance of firm specific activities through information, communication and transaction costs that would form firm's decisions in international trade and investment.

In the 1980s, John Dunning introduced Investment Development Path Theory (IDP) within the Eclectic Paradigm. Dunning and several others subsequently revised the IDP theory, still preserving the original theory.[6-10] The original IDP theory is based on the Eclectic paradigm of the international production theories which is the most important analytical framework among the recent IB theories to analyze multinationals and FDI.

The eclectic paradigm or the OLI (Ownership-Location-Internationalization) explains the existing of the multinationals and the FDI through the satisfactory conditions, namely interactions of the firm specific advantages (ownership advantages), the host country specific advantages (location advantages) and the role of imperfect external market conditions that makes internationalization an advantage for the firms.

Ownership advantages for the investing firms are essential for a firm to compete and take advantage of domestic firms when investing in an unfamiliar environment. The firms can absorb these intangible advantages from abroad through accessing knowledge of new firms and markets, new resources and to broader human capital.

Location specific advantages are critical in investment decision, that host country conditions would make foreign investment more desirable or less attractive. If there were no relative advantages of potential host country over home country, then it would be natural for the firms not to engage in international investment activities. Similarly, internationalization advantages explain how transactions costs and externalities make internalizing the activities important in the case of imperfection of the markets.

Dunning's Investment-Development Path Theory is a dynamic combination of the OLI (Eclectic) paradigm. The theory links foreign direct investment to the country level development in the basis of the investment related expansions in the OLI structures within the host country firms. According to Dunning, the difference between inward and outward foreign direct investment (Net Outward Investment -NOI-) position is a function of country's level of development. Thus, in a dynamic approach the countries follow five stages of development.

In the first stage of development, in a country Net Outward Investment is around zero because of the absence of both inward and outward investment. Insufficient location advantages do not attracts foreign investment into the country in addition to the absence of local firms with ownership advantage to invest abroad. Only natural-resource-seeking inward FDI can be observed in these economies.

At the second stage, with the existence of standard location advantages such as cheap labor, natural resources (L), faster growth of inward FDI than the GDP growth is observed. However, the domestic firms are still in the lack of country-specific ownership advantages (O) resulting in a negligible level of outward FDI. Thus, NOI position is increasingly negative in this level of development.

Third stage countries experience the decrease in the rate of growth of inward FDI while the country cannot sustain location advantages in labor-intensive sectors. But, at the same time, asset-creating location advantages began to be created. Thus, domestic firms that are owner of the capital and have knowledge to invest abroad provide higher growth of ownership advantages. In result, the rate of negative NOI slows down. In these countries, we observe still negative but increasing NOI.

The main characteristics of the fourth stage are the increase in the rate of growth of outward FDI as a result of the significance of the firm-specific ownership advantages of the domestic firms. In this stage countries generic location advantages disappears while the entire location advantages are based on asset-creation. Thus, outward FDI level is superior over the inward FDI level and a positive NOI is expected.

At the fifth stage in which we observe the most developed countries, theoretically an unstable equilibrium around zero is expected. In other words, the relationship between investment and development is no longer significant at this level.

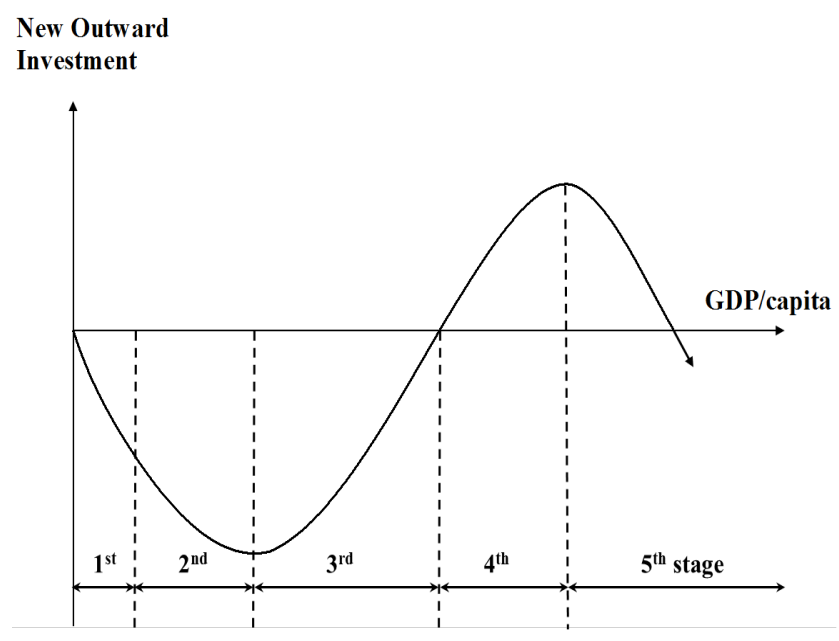

Figure 1. Investment Development Path [9]

Several empirical estimations using the IDP theory have been carried out to analyze if the relationship between investment and the development can be confirmed and if so, what stages can be validated for the sample countries. Dunning himself analyzed his theory for 67 countries from 1967 to 1978 [6] A summary of the empirical estimations are 
given in the Table 1 below.

Table 1. IDP Applications Literature Review

\begin{tabular}{|c|c|c|}
\hline Year & Author(s) & Details \\
\hline 1986 & Dunning & 25 countries \\
\hline 1989 & Pichl & 18 countries \\
\hline 1993 & Narula & Japan-US \\
\hline 1993 & Tolentino & 30 countries \\
\hline 1994 & Dunning, Narula & US-Japan \\
\hline 1996 & Dunning, Narula & 88 countries \\
\hline 1996 & Narula & 40 countries \\
\hline 1996 & Ozawa & Japan \\
\hline 1996 & Zhang, Van den Bulke & China \\
\hline 1997 & Dunning, Hoesel, Narula & Korea, Taiwan \\
\hline 1998 & Buckley, Castro & Portugal \\
\hline 1998 & Yeung & Malaysia, Singapore \\
\hline 2000 & Bellak & Austria \\
\hline 2000 & Twomey & Canada \\
\hline 2001 & Dunning et al. & Korea, Taiwan \\
\hline 2001 & Duran, Ubeda & 74 countries \\
\hline 2003 & Barry, Gorg \& McDowell & Ireland-US \\
\hline 2004 & Boudier-Bensebaa & CIS \& CEE \\
\hline 2004 & Bevan, Estrin, Meyer & Transition Econ. \\
\hline 2004 & Castro & Portugal \\
\hline 2005 & Scott-Kennel, Enderwick & Theoretical \\
\hline 2006 & Vavilov & 44 countries \\
\hline 2007 & Gorynia, Nowak, Wolniak & Poland \\
\hline 2007 & Galan, Gonzalez, Zuniga & Spain \\
\hline 2007 & Fonseca, Mendonca, Passos & Portugal \\
\hline 2008 & Sathye & India \\
\hline 2009 & Dong, Haijian, Xiaoming & China \\
\hline 2009 & Kayam, Hisarciklilar & 16 countries \\
\hline 2010 & Kun & China \\
\hline 2010 & Narula, Guimon & Eastern Europe \\
\hline 2011 & Stoian & CEE \\
\hline 2014 & Iacovoiu, Panait & $\mathrm{EU}$ \\
\hline 2014 & Liu, Buck, Yu & Japan, Korea, China \\
\hline
\end{tabular}

The studies found strong evidence to support the theory but also the limitations of the theories are argued. [11] Tolentino [12], emphasizing macroeconomic structural changes of the countries, argues the necessity of the revision of the theory. The change in the shape of the IDP curve since 1980s has also been discussed while in some studies J-shaped curve inverted to L-shaped one in empirical findings. [10] According to Narula [10], these findings stems from the use of investment flows instead of the stock data. His work on developing countries from 1975 to 1988 confirms the J-shape of the Net Outward Investment curve.
After the early applications of the theory, in 1990s the idiosyncratic nature of countries began to be argued by the authors. [9] For instance, with regard to the market size, it has been argued that time-series analysis of the small countries did not yield significant relationship between the variables or the significance of inward FDI should be analyzed separately in small market economies. [13] Vavilov [14] empirically tested that there is less support for IDP theory in natural-resource rich countries conflicting with the results of the energy importer countries. Thus, an industry level IDP estimation argued as critical.

In the midst of the era of rapid globalization, which increased the role of the FDI in all around the world, the IDP framework has been applied to several new countries in recent years. New market economies in Europe and Central Asia (CIS, CEE) and finally the fast growing East Asian countries China, India, Korea are all examined in terms of their development foreign investment relationship. (Table 1)

New stream of studies and their findings underlined the necessity of the revision of the theory [9] particularly in confirmation of the IDP's idiosyncratic nature. In addition, it is also argued that the IDP theory lacks to realize industry specific analysis in which each country has specific features that moderates the interactions of FDI and the investment.

Along with the 'updated' IDP theory, the idiosyncratic nature of the countries is accepted widely when IDP framework has been applied. It is important to recognize that each country has its own peculiar IDP reflecting their macroeconomic, institutional and political economic disparities. The lack of institutional differences, the changes towards deregulations, government policies towards foreign investment, market size, population, natural resource endowments, and human capital level are all exogenously determines the idiosyncratic IDP of the countries.

\section{Methodology}

\subsection{Data and Variables}

This study aims to inquire four emerging market economies in the era of rapid globalization of the 1990s and 2000s. During this period, similar to the other emerging economies, these economies have experience rapid growth rates in their total GDP and GDP per capita. Hence, the sample period covers the last 24 years of each of these countries from 1990 to 2013. Dataset for the country level investment were collected from the United Nations for Cooperation on Trade and Development (UNCTAD)'s Foreign Investment Database and the data for National Accounts are gathered from World Bank's World Development Indicators Database (WDI). In all the graphs, the aggregated national level data has been used and for the real numbers GDP Deflator $(2005=100)$ has been applied. Country statistics are presented in the Table 2 below. 
Table 2. Country Statistics (1990-2013) [1]

\begin{tabular}{|c|c|c|c|c|c|c|}
\hline Country & Var & I Obs & Mean & Std. Dev. & $\operatorname{Min}$ & $\operatorname{Max}$ \\
\hline Mexico & & & & & & $\begin{array}{r}-19751.63 \\
10313.24\end{array}$ \\
\hline Indonesi & noi & 24 & -55182.43 & 65503.72 & -214274 & -7431.24 \\
\hline & pgdp & 24 & 1516.937 & 957.9626 & 514.4425 & 3556.786 \\
\hline Nigeria & noi & 24 & -28685.07 & 19935.11 & -73332 & -7319.713 \\
\hline & pgdp & 24 & 707.157 & 491.3787 & 279.0578 & 1637.826 \\
\hline Turk & $\begin{array}{r}\text { noi } \\
\text { podp }\end{array}$ & $\begin{array}{l}24 \\
24\end{array}$ & $\begin{array}{r}-52187.5 \\
6090.194\end{array}$ & $\begin{array}{l}53438.83 \\
2879.313\end{array}$ & $\begin{array}{r}-164428 \\
3048.389\end{array}$ & $\begin{array}{r}-10000 \\
11041.62\end{array}$ \\
\hline
\end{tabular}

Following the IDP theory, Net Outward Investment level (NOI) which has been defined as the difference between Gross Outward Foreign Direct Investment Stock (OFDI) and Gross Inward Foreign Direct Investment Stock (IFDI) was chosen as the main dependent variable while GDP per capita and its orders are the independent variables of the model. In the literature, for theoretical analysis, FDI stocks are believed to have greater validity and explanatory power than the flows. [15] In addition, due to the lack of the IDP model in explaining the interaction between the inward and outward FDI levels, the figures of inward and outward flows by years are presented for greater inference on FDI behaviors of the MINT countries.

\subsection{Model Selection}

In empirical estimations of the IDP theory, following estimation models; quadratic form, qubic form and polynomial models [13] are used. Following the literature, in our model specification, we tested all the following models in a longitudinal data analysis and found that quadratic form (Model 1) provides the best fit for our sample.

$$
\begin{aligned}
& \text { Model }: N O I=\beta_{0 \dot{t}}+\beta_{1 \dot{t}} P G D P+\beta_{2 \dot{t}} P G D P^{2}+\varepsilon_{t} \\
& \text { Model2: } N O I=\beta_{0 \ddot{t}}+\beta_{1 \dot{t}} P G D P+\beta_{2 \vec{t}} P G D P^{2}+\beta_{3 \vec{u}} P G D P^{3}+\varepsilon_{t} \\
& \text { Model3: } N O I=\beta_{0 \dot{u}}+\beta_{1 \vec{t}} P G D P+\beta_{2 \dot{t}} P G D P^{2}+\beta_{3 \vec{t}} P G D P^{3}+\beta_{4 \dot{t}} P G D P^{4}+\beta_{5 \dot{t}} P G D P^{5}+\varepsilon_{t} \\
& \text { Model }: N O I=\beta_{0 i t}+\beta_{1 \dot{t}} P G D P+\beta_{3 \vec{t}} P G D P^{3}+\beta_{5 \dot{t}} P G D P^{5}+\varepsilon_{t}
\end{aligned}
$$

Model 1, quadratic equation model, best explains the relationship between NOI and PGDP with high R-square results with significant $t$ values for variables and errors at $99 \%$ confidence interval. Although it provides high power of explanation (high R-squared results) and significant results, polynomial Model 3 is not preferred for regression analysis because of the limited number of observations, 24, in the dataset for each country. Methodologically, earlier works show that time-series analysis does not provide significant relationship between investment and GDP per capita and cross-sectional analysis produces clustering of observations. [16] Thus, in this paper a longitudinal data analysis with fixed effect is preferred for its

\begin{tabular}{|c|c|c|c|c|}
\hline VARIABLES & $\begin{array}{c}\text { (1) } \\
\text { Model } 1\end{array}$ & $\begin{array}{c}(2) \\
\text { Model } 2 \\
\end{array}$ & $\begin{array}{c}(3) \\
\text { Model } 3\end{array}$ & $\begin{array}{c}(4) \\
\text { Model } 4\end{array}$ \\
\hline Pgdp & $\begin{array}{c}-62.24 \star \star \star \\
(6.510)\end{array}$ & $\begin{array}{c}-57.61 * \star \star \\
(10.78)\end{array}$ & $\begin{array}{c}20.87 \\
(27.53)\end{array}$ & $\begin{array}{c}-49.63 * * * \\
(6.148)\end{array}$ \\
\hline pgdp2 & $\begin{array}{l}0.00270 * \star \star \\
(0.000482)\end{array}$ & $\begin{array}{c}0.00148 \\
(0.00231)\end{array}$ & $\begin{array}{c}-0.0584 * \star \star \\
(0.0161)\end{array}$ & \\
\hline pgdp3 & & $\begin{array}{c}7.89 e-08 \\
(1.46 e-07)\end{array}$ & $\begin{array}{c}1.66 \mathrm{e}-05^{\star \star \star} \\
(3.72 \mathrm{e}-06)\end{array}$ & $\begin{array}{c}1.24 \mathrm{e}-07 \\
(1.09 \mathrm{e}-07)\end{array}$ \\
\hline pgdp4 & & & $\begin{array}{c}-1.86 e-09 * k \star \\
(3.74 e-10)\end{array}$ & \\
\hline pgdp5 & & & $\begin{array}{l}0 * \star \star \\
(0)\end{array}$ & $\begin{array}{c}0 \\
(0)\end{array}$ \\
\hline Constant & $\begin{array}{c}103,112 \star \star \star \\
(13,625)\end{array}$ & $\begin{array}{c}100,280 \star \star \star \\
(14,651)\end{array}$ & $\begin{array}{c}76,477 \star \star \star \\
(14,479)\end{array}$ & $\begin{array}{c}92,832 \star \star * \\
(13,799)\end{array}$ \\
\hline Observations & 96 & 96 & 96 & 96 \\
\hline R-squared & 0.778 & 0.779 & 0.843 & 0.779 \\
\hline Number of country & 4 & 4 & 4 & 4 \\
\hline
\end{tabular}
explanatory power, but panel analysis needs a large data set particularly in high powered regression models. Thus, the quadratic form is chosen over the polynomial model to avoid the constraints of panels.

Table 3. Model Specifications 
Table 4. Panel Regression Results (Model 1)

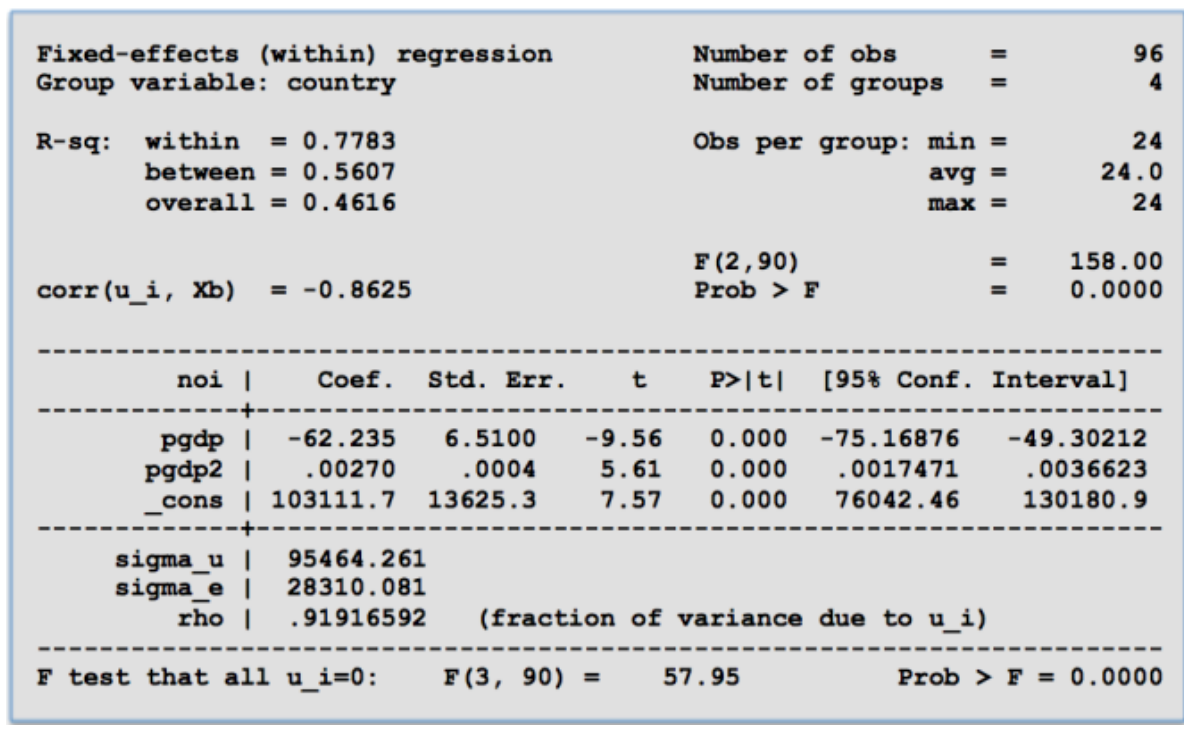

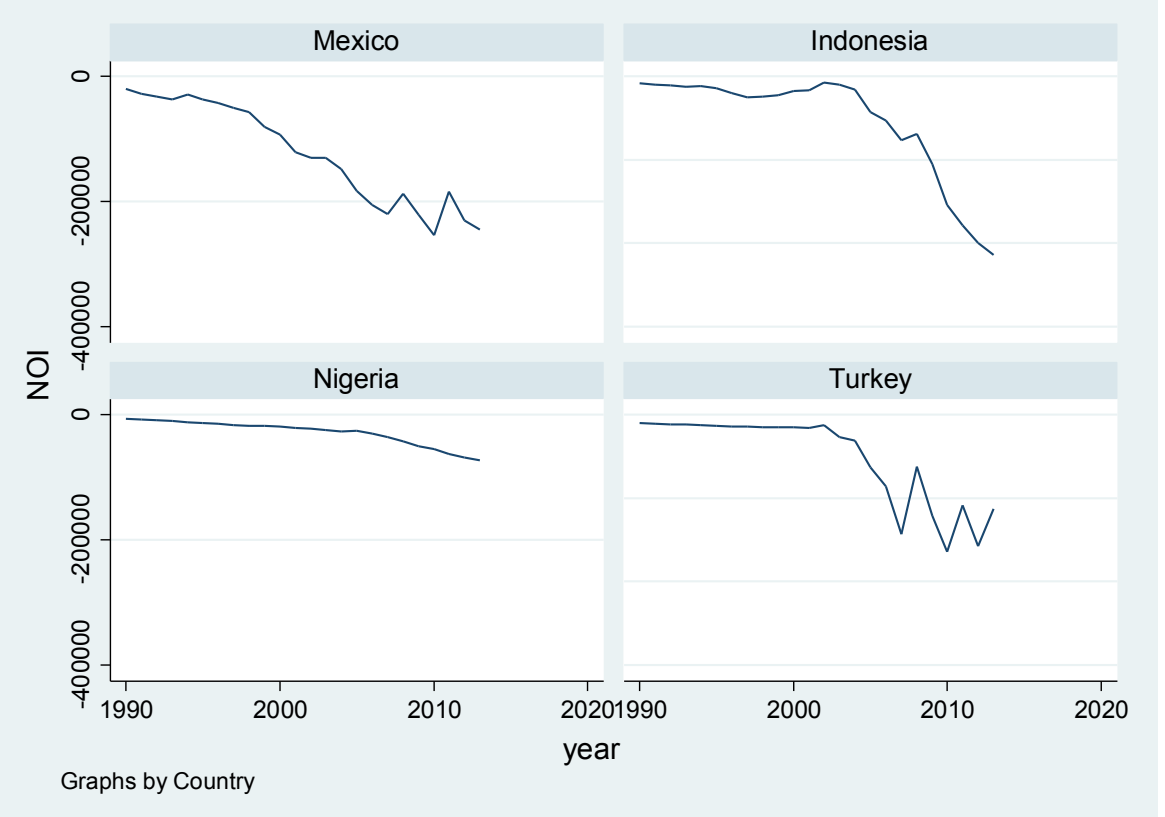

Figure 2. Net Outward Investment Positions of MINT economies

\section{Empirical Results and Discussions}

There are four important findings in this paper. First, the four countries have very similar positions and behaviors in their foreign investment levels. Considering their GDP per capita, the result is consistent with the theoretical prediction of the IDP Model.

Second, a high level of decrease in Net Outward Investment (NOI) in the last 23 years proves that all four countries are in the second stage of their investment development path and their development accelerated in 2000s and increased its speed over time. By theory, increasing amount of investment level into the countries is common for all 2nd stage countries, but it is also observed in MINT countries that 'increasingly negative' trend in NOI position is fast, that the coefficient of the PGDP variable is very high proving the significance of the foreign investments into the emerging countries (IFDI). The increasingly negative slope of the NOI, the speed and the direction of the IDP curve for all countries confirm the role of Inward FDI in the development of MINT economies.

The following graph demonstrates how inward FDI flows in all four countries are increasingly negative while the countries grow over time. Mexico, the highest in per capita GDP, has the highest share in IFDI flows while Nigeria, group's lowest in per capita GDP, receive relatively lower investment inflows. These results also supports our argument that the development of the MINT countries strongly dependent to the investment inflows at this stage.

Third, there is a gradual increase in Outward FDI levels of 
the MINT countries that is critical for the sustainability of their growth. In the competitive environment of the international business, firms from emerging countries need to absorb location advantages abroad and should seek and absorb tangible or intangible assets through globalization. [7]

According to the OFDI flows by country, particularly Mexican OFDI level demonstrates that the more developed the country in terms of per capita income level, the more investment flows from the home country to abroad. In this regard, the observation of Nigeria is also consistent with the theory. Considering the higher per capita GDP of Turkey over Indonesia, Turkish firms have poor performance in investing abroad. In other words, Indonesia has potential for higher growth rates through exploiting location advantages abroad and expanding ownership advantages of the local firms. OFDI is seen key for the future development and for a possible shift in country development position while technology, knowledge and absorptive capabilities of the firms shape the new global competitive environment. Thus, the local firms from MINT should make critical OFDI decisions for catching-up.

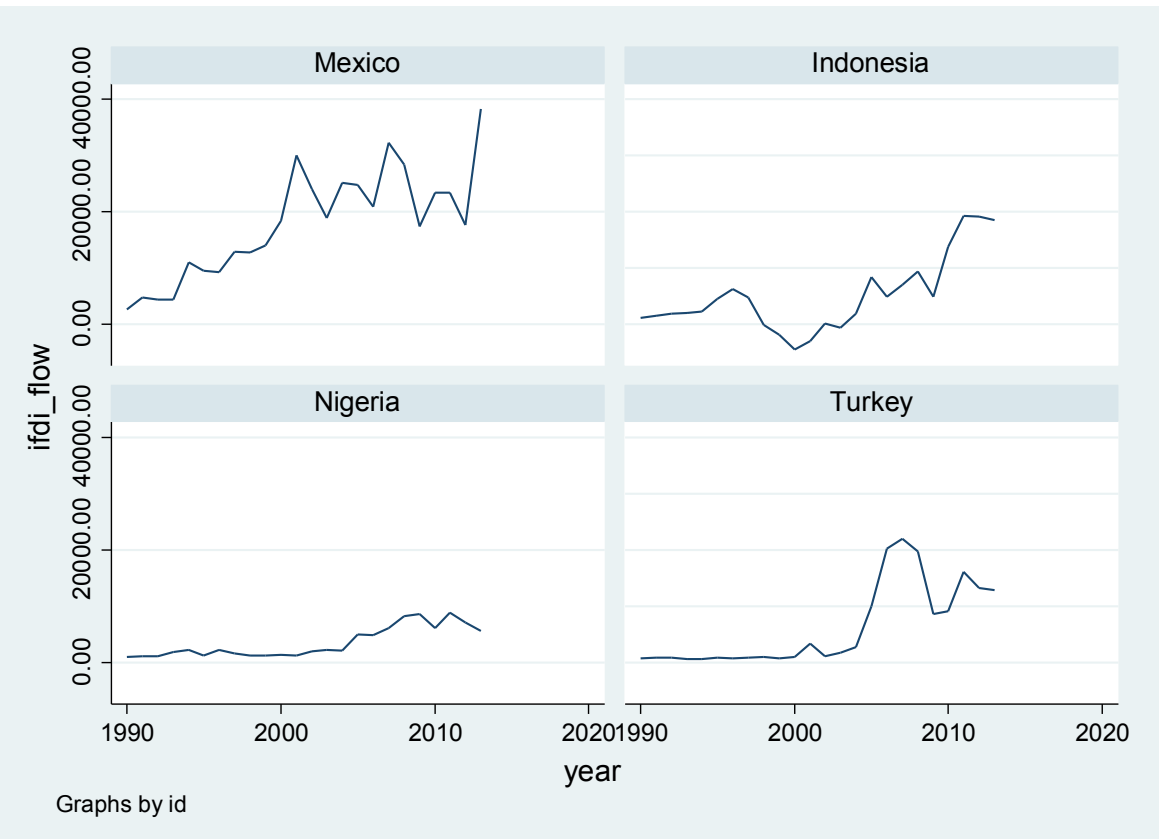

Figure 3. FDI Inflows

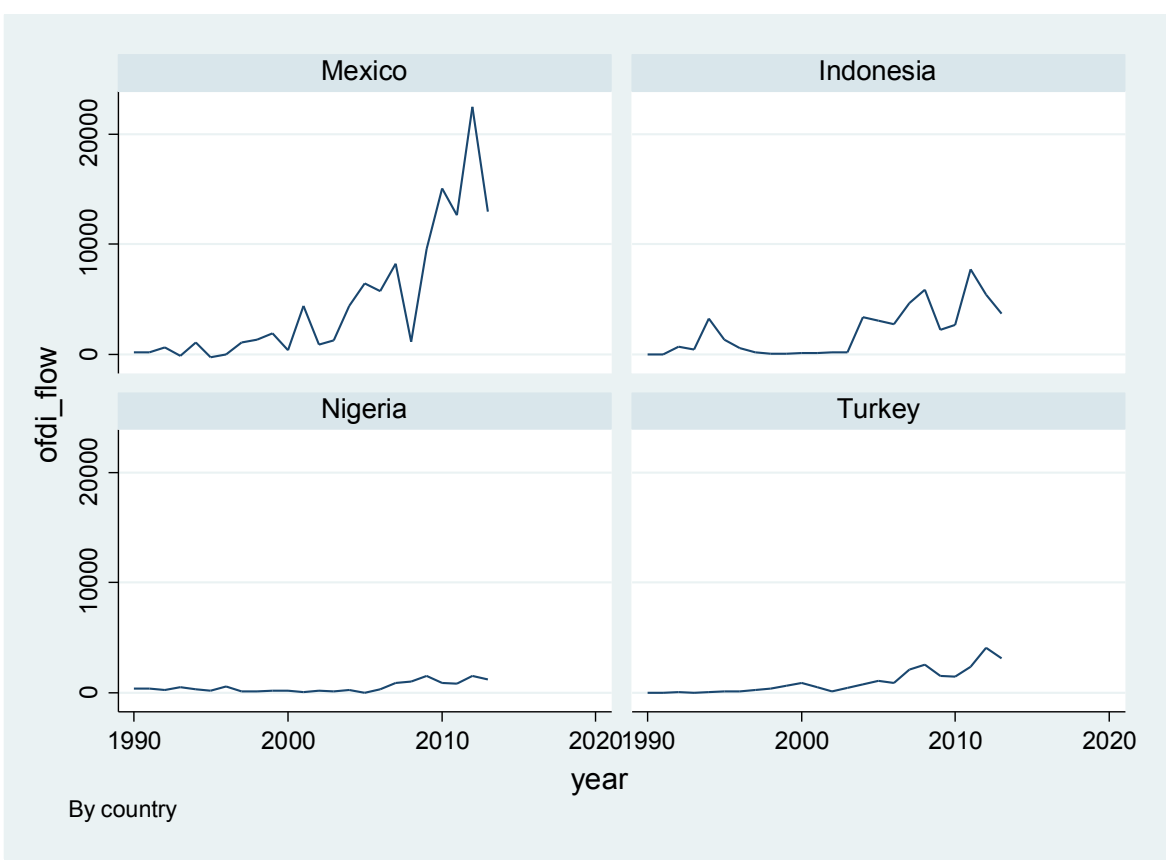

Figure 4. FDI Outflows 


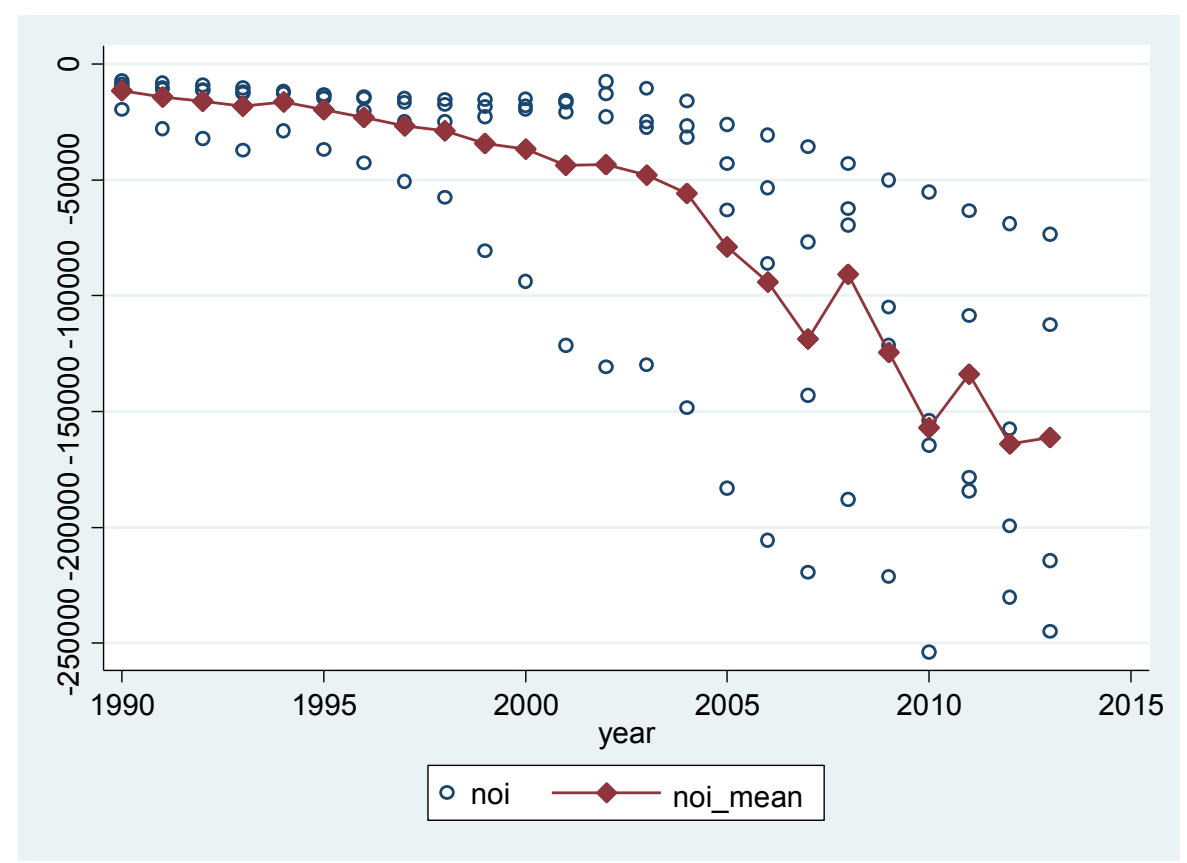

Figure 5. Heterogeneity of NOI across Years

As a final result, it should be noted that our findings are consistent with the standard IDP model and emphasizes similarities of the group countries over the idiosyncratic disparities. Even detailed analysis of the IFDI and OFDI proves similar patterns in investment behaviors of MINT economies.

\section{Concluding Remarks}

The results in this study is evidence that in the last twenty years MINT economies has rapidly experienced the second stage of IDP and are transforming to the third stage of development. Detailed analysis of outward and inward FDI flows also demonstrates that during the emerging of these emerging economies in the international economy foreign investment, particularly inward FDI from abroad, played a significant role.

Although there are several macroeconomic, institutional and policy based factors affecting a country's growth rate, annual investment flows given in this study prove the potential of MINT economies for sustainable growth. Actually, the main contribution of this paper is that it provides new insights and supports for the argument "MINT has potential to be the new BRICS". In this paper, this argument is tested through MINT's FDI positions and we have evidence that IDP analysis confirms the potential investment position of the MINT economies.

On the other hand, the power of IDP theory is limited for a strong prediction on the investment potential of the countries. MINT cannot be a good alternative if its advantages only sit on the basis of labor-intensive sectors of manufacturing and market seeking FDI limits. In this regard, Chinese growth is one of a kind. None of the countries under investigation are large in size as China. Giving that population growth is relatively limited and political stability is controversial, the future of these economies lies in their ability to exploit OLI advantages through internationalization. However, if the competitive environment in their market is only shaped by the demand, then for these countries there are limits of growth and development. In addition, OLI paradigm shows that depending only to the inward FDI cannot provide sustainable growth. From this perspective, in our analysis the increase in OFDI which is critical to understand the direction and the speed of the NOI movement toward the third stage is found relatively slow.

Development story of the emerging economies continues in a very competitive global business environment. They face very high level of competition both at local and international markets. Under the challenges of higher competition, in order to survive and catch-up, higher investment abroad is necessary by the emerging economies and their multinationals at their earlier stage of development. If the domestic firms of these countries achieve exploiting tangible and intangible assets abroad, then it would be possible for them to be successful competitors for already existing global firms. That is, outward investment is not sufficient but necessary to generate both firm and country specific ownership advantages for the firms from emerging markets. Similarly, as second-generation developing country group assuming the challenges faced by MINT are much intense, exploitation of competitive advantage abroad is even more critical for them. That is, OFDI investment at the earlier stages of their development is very decisive for MINT countries to survive and compete.

MINT can be a good alternative as investment destination 
of cost and market seeking foreign firms, but for their ultimate development goal these countries should expand their country and firm specific ownership advantages. The governments of these countries should pursue policies to attract asset and knowledge-seeking FDI into their countries in addition to the policies to achieve better infrastructure and human capital.

\section{REFERENCES}

[1] UNCTAD, World Investment Report 2014., Online available from http://unctad.org/en/PublicationsLibrary/wir2014_en.p df

[2] Y. Aharoni, R. Ramamurti. The Evolution of Multinationals, Research in Global Strategic Management, Vol. 15, Emerald Group Publishing Limited, 113-135, 2011.

[3] J. O'neill. Who you calling a BRIC?, Bloomberg Week. Available online from www.bloombergview.com/articles/2013-11-12/who-you-call ing-a-bric-

[4] World Bank World Development Indicators 2014-6. Available online from http://data.worldbank.org/products/wdi

[5] R. Vernon. International Investment and International Trade in the Product Cycle. Quarterly Journal of Economics, Vol. 80, 190-207.

[6] J.H. Dunning. The Investment Development Cycle Revisited, Weltwirtschaftliches Archive, Vol. 122, 667-677, 1986.
[7] J.H. Dunning. The eclectic paradigm of international production: A restatement and some possible extensions, Journal of International Business Studies, Vol. 19, No. 1, 1-31, 1988.

[8] J.H. Dunning. Multinational Enterprises and the Global Economy, Massachusetts: Addison-Wesley Publishing, 1993.

[9] J.H. Dunning, R. Narula. The Investment Development Path Revisited: Some emerging issues, Routledge, London and New York, 1996.

[10] R. Narula, Multinational Investment and Economic Structure: Globalization and Competitiveness, Routledge, London and New York, 1996.

[11] V. Iacovoiu, M. Panait. The Limitation of Investment Development Path Theory: European Union Case, Economic Insights-Trends and Challenges, Vol. 3, No. 67, 33-40, 2014.

[12] P.E. Tolentino. Technological Innovation and Third World Multinationals, Routledge, London and New York, 1993.

[13] P. J. Buckley, F.B. Castro. The Investment Development Path: The case of Portugal, Transnational Corporations, Vol. 7, No. $1,1-15,1998$.

[14] S. Vavilov, Investment Development Path in Petroleum Exporters, Université Paris I Panthéon - Sorbonne, 43, 2006

[15] M. Fonseca, et al., The Investment Development Path Hypothesis: Evidence from the Portuguese Case - a panel Data Analysis, Working Paper, 21/2007/DE, School of Economics and Business Administration, Technical University of Lisbon, 2007.

[16] C. Bellak. The Investment Development Path of Austria, Department of Economics Working Paper Series, No. 75, 31, 2000. 